\title{
Evaluation of Different Pea (Pisum sativum L.) Varieties for High Yield Production Under Agro-climatic Condition of Hazara Division
}

\author{
Zain Ul Islam ${ }^{1}$, Seemab Ashraf ${ }^{1}$, Haq Nawaz ${ }^{2 *}$, Hafiz Muhammad \\ Bilal $^{3}$, Aamir Umar ${ }^{1}$, Noor Jameel ${ }^{1}$, Awais Anwar ${ }^{4}$ and Shukaib Anwar ${ }^{5}$ \\ ${ }^{1}$ Department of Agriculture Faculty of Sciences Hazara University Mansehra, \\ Pakistan \\ ${ }^{2}$ Department of Field Crops, Faculty of Agriculture, Isparta University of Applied \\ Sciences, Turkey \\ ${ }^{3}$ Department of Horticulture, Faculty of Agriculture, Isparta University of Applied \\ Sciences, Turkey \\ ${ }^{4}$ Arid Agriculture University, Rawalpindi, Pakistan \\ ${ }^{5}$ University of Haripur, Pakistan \\ *Corresponding Author: Haq Nawaz, Department of Field Crops, Faculty of \\ Agriculture, Isparta University of Applied Sciences, Turkey.
}

\begin{abstract}
The performance of six pea varieties were evaluated at Hazara University Dhodihal, Mansehra KPK, and Pakistan in mid of August. The present studies of Six varieties (Climax, Pasan, Rondo, Meteor, Green feast and Sarsabz 980-1) were evaluated for their plant vegetative and reproductive growth (seed germination, days to $50 \%$ flowering, plant height, number of branches per plant, number of pods) and physical properties (pod length, pod weight and seed weight) of the peas. The experimental trial was laid out in randomized complete block (RCBD), consisting of 6 treatments (varieties) replicated three times and five selected tagged plants were taken as an experimental unit; the data were collected and analyzed according to standard analytical formula. The results showed the maximum seed germination were found in meteor (90\%), the varieties meteor showed that minimum number of days, required to attain 50\% flowering, maximum plant height was recorded in climax $(92.1 \mathrm{~cm})$, maximum number of branches/plant was recorded in meteor (5.4), maximum number of pods was recorded in meteor (14.5), maximum pod weight was recorded in meteor (24.2kg). maximum 100g seed weight was recorded in meteor (19.7g). From research experiments it was concluded that Pea variety Meteor was best showing results for being cultivated in Hazara division.
\end{abstract}

Keywords: Pisum sativum; Yield; Seed

\section{Introduction}

Peas (Pisum sativum L.) a grain legume, a member of the leguminoseae family and native of central or South east Asia, is an excellent human food. It is either eaten as a vegetable or used in the preparation of soups. In addition to that it is also used as animal feed [1] has reported that pea seed is Pisum sativum highly nutritious and approximately half the world production is fed to livestock while the remaining portion is used for human food, primarily in developing counties.

The peas are full of nutrition because its grain is rich in protein (27.8\%), complex carbohydrates (42.65\%), vitamins, minerals, di- 
etary fibers and antioxidant compounds [2]. Among grain legumes Pea ranks 4thin the world on production basis after soybean, groundnut and French beans. Dry pea is produced in more than 87 countries worldwide with approximately one-half the world's production occurring in Canada, France, China and Russia. Other leading pea producing countries include India, Ukraine, Germany, Australia, United Kingdom and United States. In Pakistan, pea is an important crop, which plays a major role in farmer's economy. It is the most common crop and enjoys a great commercial demand due to its nutritive value. It is cultivated during winter in plains and during summer in highlands [3]. It represents about $40 \%$ of the total trade in pulses.

The area under cultivation of pea crop in Pakistan is 22436 hectares with production of 144422 tonnes. While in KPK pa crop area under cultivation is 1942 hectares with total production 13418 tonnes [4]. In Pakistan it is cultivated under an extensive range of agricultural regions, but the average yield per hectare is very low as compared to its potential and yield obtained in many other countries.

Out of many constrains which limit the pea economical crop growth, the main hindering factor is improper combination of different chemical fertilizers. As compared to many other countries, the average yield of pea crop is very low in Pakistan which may be attributed due to the non-adoption of improved varieties [5] have also reported that variability in old, unimproved varieties needs to be determined in order to create useful genetic variation for broadening the narrow genetic base of commercial cultivars and for making efficient use of available resources.

The other factors like non usage of recommended agronomic practices, application of improper fertilizer doses; diseases and harvesting losses also play an important role in yield reduction. According to [6] the main hurdle in the way of increasing per hectare pea production is the weed competition. Sometimes season long crop-weed competitions reduce the green pod yield by up to 45 $55 \%$ [7]. In addition to these, environmental factor such as rainfall also affects yield [8] have also reported that seed yield in pea is highly dependent on environment and is particularly responsive to the amount and distribution of precipitation received during the growing season. Keeping all these issues in view, present research work was designed to evaluate the available material for yield other agronomic traits for Hazara division.
Keeping in the view the commercial value of pea plant in Hazara region the present investigation was carried out to find evaluation the high yielding pea varieties under agro climatic condition of Hazara division in order to minimize the economic losses. Performing of different promising pea varieties under agro climatic condition of Hazara division. Effect on yield of pea varieties.

\section{Materials and methods}

The present investigation was carried out at experimental farm Hazara University Dhodihal, Mansehra to evaluate the suitable variety for the commercial cultivation of pea in Hazara Division. The experimental plot was laid out in randomized complete block design with three replications. The varieties used were Climax, Passan, Rondo, Meteor, Green feast and Sarsabz 980-1.The seeds were sown on $13^{\text {th }}$ of August, 2019 in a well-prepared bed size of $5 \times 3$ $\mathrm{m} 2$. Row to row and plant to plant spacing was maintained at $45 \mathrm{x}$ $20 \mathrm{~cm}$.

All the standard agronomic practices were followed throughout the growing season and recommended a dose of fertilizer was applied for the better nourishment of plants. Farm Yard Manure was applied @ of $1000 \mathrm{~kg} \mathrm{ha}^{-1}$ before sowing while DAP@ $250 \mathrm{~kg} \mathrm{ha}^{-1}$ at the time of sowing. The first irrigation was given immediately after sowing, second irrigation at after a week and subsequent irrigations at an interval of 10 days.

\section{Data collection and data analysis}

The data were recorded on randomly selected five tagged plants of each pea varieties. Following observations were recorded during the course of study on \% germination, Days to $50 \%$ flowering, plant height, number of branches plant-1, number of pods plant-1, pods length, pods weight, and pods yield $\mathrm{kg} \mathrm{ha}^{-1}$. The following varieties were evaluated during study.

\begin{tabular}{|c|c|}
\hline S. No & Varities \\
\hline 1 & Climax \\
\hline 2 & Meteor \\
\hline 3 & Rondo \\
\hline 4 & Sarsab 980-1 \\
\hline 5 & Green feast \\
\hline 6 & Passan \\
\hline
\end{tabular}

Table 1 
The recorded data were subjected to the analysis of variance technique and the significant means were subsequently separated by the lysergic acid diethylamide (LSD) test [9].

\section{Results}

In order to explore the adoptability of different pea varieties that may exist in the experimental material, data was recorded on various growth parameters i.e. seed germination percentage, days to $50 \%$ flowering, plant height and 100 seed weight respectively. Significant association between these traits has been reported by [10].

\begin{tabular}{|l|c|c|c|c|}
\hline Trait & $\begin{array}{c}\text { Rep } \\
(\mathbf{d f = 2})\end{array}$ & $\begin{array}{c}\text { Varieties } \\
(\mathbf{d f = 5})\end{array}$ & $\begin{array}{c}\text { Error } \\
(\mathbf{d f = 1 0})\end{array}$ & $\begin{array}{c}\text { C.V } \\
\mathbf{( \% )}\end{array}$ \\
\hline Seed germination (\%) & 9.556 & $275.956^{* *}$ & 6.289 & 3.18 \\
\hline Days to 50\% flowering & 13.617 & $357.476^{* *}$ & 5.477 & 3.11 \\
\hline $\begin{array}{l}\text { Number of branches per } \\
\text { plant }\end{array}$ & 0.51345 & $2.67032^{* *}$ & 0.15722 & 10.38 \\
\hline Plant height & 17.83 & $1121.84^{* *}$ & 8.64 & 129.81 \\
\hline Number of pods & 3.8566 & $19.5136^{* *}$ & 1.1767 & 10.14 \\
\hline Pod length & 4.00056 & $6.49893^{* *}$ & 0.74041 & 12.04 \\
\hline Pod weight & 2.2993 & $27.5795^{* *}$ & 2.2386 & 7.58 \\
\hline Seed weight & 5.8867 & $13.2667^{* *}$ & 0.8293 & 5.29 \\
\hline
\end{tabular}

Table 2: Mean square values for seed germination percentage (\%) days to $50 \%$ flowering (DF) number of branches per plant (NBP) plant height $(\mathrm{PH})$ number of pods (NP) pod length (PL) pod weight (PW) and seed weight (SW).

\begin{tabular}{|c|c|c|c|c|c|c|c|c|}
\hline Varieties & SG & DF & NBP & PH & NP & PL & PW kg/plot & 100 gm SW \\
\hline Meteor & $92 \mathrm{a}$ & $91 \mathrm{a}$ & $5.4 \mathrm{a}$ & $92.1 \mathrm{a}$ & $14.5 \mathrm{a}$ & $9.03 \mathrm{a}$ & $24.2 \mathrm{a}$ & $19.7 \mathrm{a}$ \\
\hline Green feast & $86.6 \mathrm{~b}$ & $85 \mathrm{~b}$ & $4.3 \mathrm{~b}$ & $86.02 \mathrm{~b}$ & $13.1 \mathrm{a}$ & $8.3 \mathrm{a}$ & $21.7 \mathrm{ab}$ & $19.5 \mathrm{a}$ \\
\hline Climax & $81 \mathrm{c}$ & $76.4 \mathrm{C}$ & $3.6 \mathrm{bc}$ & $77.1 \mathrm{c}$ & $9.7 \mathrm{~b}$ & $8.01 \mathrm{a}$ & $19.6 \mathrm{~b}$ & $17.5 \mathrm{~b}$ \\
\hline Passan & $76 \mathrm{~d}$ & $68.6 \mathrm{~d}$ & $2.8 \mathrm{~d}$ & $65.3 \mathrm{~d}$ & $9.4 \mathrm{~b}$ & $6.06 \mathrm{~b}$ & $19.9 \mathrm{~b}$ & $14.4 \mathrm{c}$ \\
\hline Sarsabz 98 & $66.3 \mathrm{f}$ & $66.6 \mathrm{de}$ & $3.4 \mathrm{~cd}$ & $45.1 \mathrm{e}$ & $8.6 \mathrm{~b}$ & $5.6 \mathrm{~b}$ & $16.2 \mathrm{c}$ & $15.9 \mathrm{bc}$ \\
\hline Rando & $71.3 \mathrm{e}$ & $63.6 \mathrm{e}$ & $3.2 \mathrm{~cd}$ & $49.1 \mathrm{e}$ & $8.5 \mathrm{~b}$ & $5.7 \mathrm{~b}$ & $16.7 \mathrm{c}$ & $16.03 \mathrm{bc}$ \\
\hline LSD $(0.05)$ & 4.5623 & 4.2577 & 0.7213 & 5.3482 & 1.9735 & 1.5654 & 2.7220 & 1.6568 \\
\hline
\end{tabular}

Table 3: Mean values for seed germination percentage (\%) days to $50 \%$ flowering (DF) number of branches per plant (NBP) plant height (PH) number of pods (NP) pod length (PL) pod weight (PW) and seed weight (SW).

\begin{tabular}{|c|c|c|c|}
\hline S. No & Varities & Yield kg/plot & Yield tonnes/hac \\
\hline 1 & Meteor & $358.5 \mathrm{a}$ & 3585 \\
\hline 2 & Green feast & $354.5 \mathrm{ab}$ & 3545 \\
\hline 3 & Climax & $284 \mathrm{~b}$ & 2840 \\
\hline 4 & Passan & $266.7 \mathrm{~b}$ & 2667 \\
\hline 5 & Sarsabz 98 & $248.4 \mathrm{c}$ & 2484 \\
\hline 6 & Rando & $249.1 \mathrm{c}$ & 2491 \\
\hline & LSD (0.05) & 2.722 & \\
\hline
\end{tabular}

Table 4: Mean Square values for Yield.

Seed germination

Pea variety Meteor stood at par among the seven tested genotypes having maximum germination percentage of $90 \%$ followed by pea variety Green feast having $86 \%$ germination. Two varieties were fallen in intermediate group and seed germination percentage ranges from 60 to $70 \%$. Passon has 70\%, Sarsabz 9800-1
$66 \%$, Rondo $71 \%$ has $60 \%$ germination percentage respectively. Our result coincided with that of [8] have reported that seed germination is affected by physiological age of the seed at harvest and subsequent handling. In addition to this, harvesting time, harvesting, threshing methods and storage conditions also affect the seed viability [11].

\section{Days to flowering}

According to the results, days to flowering revealed significant differences (P\&lt; 0.05) in table 1. Result showed that minimum Number of days required to attain $50 \%$ flowering data revealed significant differences in Meteor (63.6) followed by Green feast (68.6) among the pea varities. While maximum number of days attained by Rondo (91) followed by Passon (85) respectively. Climax attained (76.4) days to attain 50\% days to flowering. Our result matched with that of [12] also reported that pea cultivars have a sufficiently wide range of duration of vegetative period and their consequent phases (flowering, maturation etc.). 


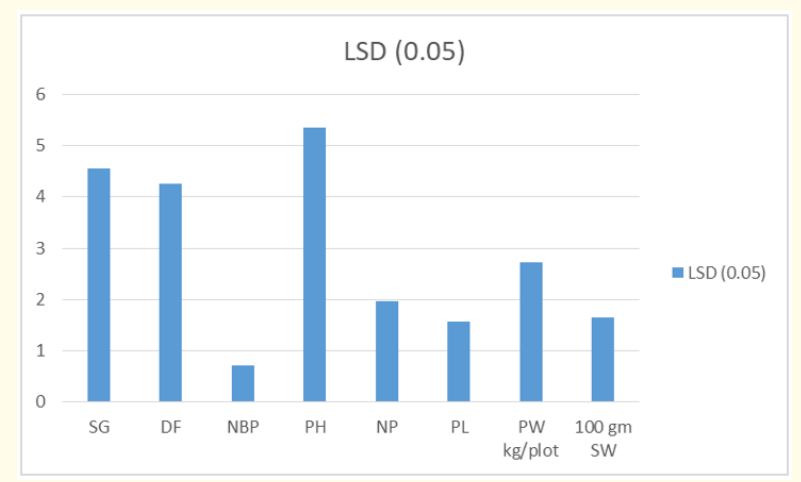

Figure 1

\section{Plant height}

In our experiment data for plant height range from $40 \mathrm{~cm}$ to $90 \mathrm{~cm}$. According to results in showed that Maximum plant height (92.1) was recorded for pea variety Climax, followed by Green feast, Meteor having (65.3) and (77.1) plants height respectively. Pea variety Passon was having $77.1 \mathrm{~cm}$ plant height followed by Rondo having (49.1) while lowest value for this parameter was recorded for local variety Sarsabz $(45.1 \mathrm{~cm})$. Pea variety Meteor with medium plant height gave maximum fresh pod yield showing and proving that selection criteria should be based on this. Our result coincided with [13] reported that significant variability existed in Pea genotypes and Plant Height is among those triat having positive and greater influences. Similarly difference in plant height among Pea cultivars were reported by [14].

\section{No of branches/plant}

According to results showed that maximum No of branches/ plant (5.4) was observed in Meteor followed by Green Feast (4.3) are significantly different from each other. While minimum No of branches were observed in Passon (2.8) pea variety followed by Climax (3.6), Sarsabz (3.4) and Rondo (3.2) respectively. Analyzed data reveals significant difference among all varieties.

\section{Pods plant ${ }^{-1}$}

Maximum green pod/plant was recorded for pea variety Meteor having 14.5 closely followed by Green Feast (13.1) respectively. While Climax and Passon stood $3^{\text {rd }}$ having 9.7 and 9.4 pods/plant and fall in intermediate group. While minimum No of pods was recorded in Rando 8.5 and Sarsabz 8.6 respectively. Our result resem- bled with [15] has reported that Meteor gave maximum production as compared to Climax in his experiment on pea.

Pods weight (G)

Pod Weight Statistical analysis of the data showed that differences in pod weight of the different varieties were significant. Variety Meteor ranked first maximum pod weight of $24.2 \mathrm{~kg}$ plot-1, followed by Green feast with $21.75 \mathrm{~kg}$ plot-1 stood second. Variety Sarsabz produced the minimum pod weight (16.20 kg plot-1). A higher number of pods plot-1 is attributed to the higher pods weight. These results are in conformation with those of $[16,17]$.

\section{Seed weight $(\mathrm{g})$}

According to data, Maximum 100 Seed weight was recorded for pea variety Meteor having 19.7 closely followed by Green feast (19.5) respectively. While Passon and Climax stood $3^{\text {rd }}$ having 19.9 and 19.6 gm seed weight and fall in intermediate group. While minimum No of 100 gm seed weight was recorded in Rando 16.7 and Sarsabz 16.2 respectively. Our result resembled with [15] has reported that Meteor gave maximum production as compared to Climax in his experiment on pea.

Yield

Data revealed that there was significant difference among various pea varieties. The table 2 shows that maximum yield was observed in Meteor (3585 tonnes/hac) followed by Green feast (3545 ton/ha) respectively. While minimum yield production attained by Sarsabz variety (2484 ton/ha) followed by Rondo (2491 tonnes/ hac). Variety Climax (2840tons/ha) and Sarsabz (2489 ton/ha) ranked third in yield respectively.

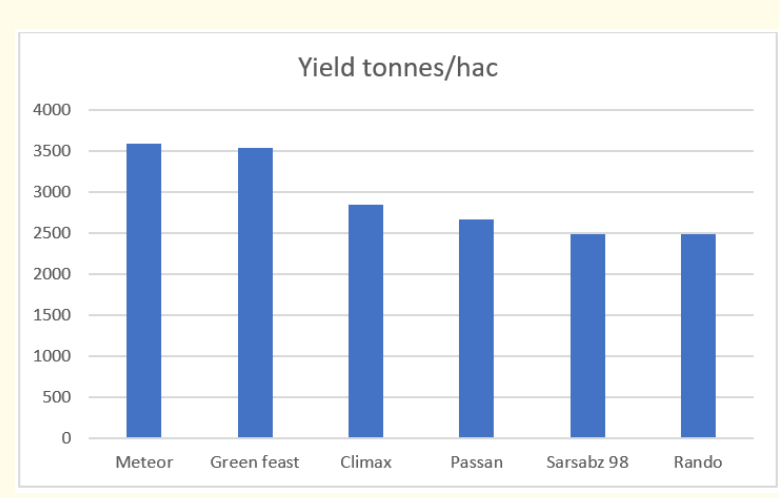

Figure 2 


\section{Discussion}

The present investigation was carried out at experimental trial at the farm of Hazara University Dhodihal, Mansehra to evaluate the suitable variety for the commercial cultivation of pea in Hazara Division. The experimental plot was laid out in randomized complete block design with three replications. The varieties used were Climax, Passan, Rondo, Meteor, Green feast and Sarsabz 9801.The seeds were sown on $13^{\text {th }}$ of August, 2019 in a well-prepared bed size of $5 \times 3 \mathrm{~m} 2$. Row to row and plant to plant spacing was maintained at $45 \times 20 \mathrm{~cm}$. All the standard agronomic practices were followed throughout the growing season and recommended a dose of fertilizer was applied for the better nourishment of plants. Farm Yard Manure was applied @ of $1000 \mathrm{~kg} \mathrm{ha}^{-1}$ before sowing while DAP @ 250 kg ha-1 at the time of sowing. The first irrigation was given immediately after sowing, second irrigation at after a week and subsequent irrigations at an interval of 10 days. Pea variety Meteor stood at par among the seven tested genotypes having maximum germination percentage of $90 \%$ followed by pea variety Green feast having $86 \%$ germination. Two varieties were fallen in intermediate group and seed germination percentage ranges from 60 to $70 \%$. Passon has $70 \%$, Sarsabz 9800-1 66\%, Rondo 71\% has $60 \%$ germination percentage respectively. Days to flowering revealed significant differences (P\&lt; 0.05). Result showed that minimum Number of days required to attain 50\% flowering data revealed significant differences in Meteor (63.6) followed by Green feast (68.6) among the pea varieties. While maximum number of days attained by Rondo (91) followed by Passon (85) respectively. Climax attained (76.4) days to attain $50 \%$ days to flowering. Plant height range from $40 \mathrm{~cm}$ to $90 \mathrm{~cm}$. Maximum plant height (92.1) was recorded for pea variety Climax, followed by Green feast, Meteor having (65.3)and( 77.1)plants height respectively. Pea variety Passon was having $77.1 \mathrm{~cm}$ plant height followed by Rondo having (49.1) while lowest value for this parameter was recorded for local variety Sarsabz $(45.1 \mathrm{~cm})$. Pea variety Meteor with medium plant height gave maximum fresh pod yield showing and proving that selection criteria should be based on this. Maximum No of branches/plant (5.4) was observed in Meteor followed by Green Feast (4.3) are significantly different from each other. While minimum No of branches were observed in Passon (2.8) pea variety followed by Climax (3.6), Sarsabz (3.4) and Rondo (3.2) respectively. Analyzed data reveals significant difference among all varieties. Maximum green pod/plant was recorded for pea variety Meteor having 14.5 closely followed by Green Feast (13.1) respectively. While Climax and Passon stood 3rd having 9.7 and 9.4 pods/plant and fall in intermediate group. While minimum No of pods was recorded in Rando 8.5 and Sarsabz 8.6 respectively. Variety Meteor ranked first maximum pod weight of $24.2 \mathrm{~kg}$ plot-1, followed by Green feast with $21.75 \mathrm{~kg}$ plot-1 stood second. Variety Sarsabz produced the minimum pod weight (16.20 kg plot-1). A higher number of pods plot- 1 is attributed to the higher pods weight. Maximum 100 gm Seed weight was recorded for pea variety Meteor having 19.7 closely followed by Green feast (19.5) respectively. While Passon and Climax stood $3^{\text {rd }}$ having 19.9 and 19.6 gm seed weight and fall in intermediate group. While minimum No of 100 gm seed weight was recorded in Rando 16.7 and Sarsabz 16.2 respectively. Maximum yield was observed in Meteor (3585 tonnes/hac) followed by Green feast (3545 tonnes/hac) respectively. While minimum yield production attained by Sarsabz variety (2484 tonnes/hac) followed by Rondo (2491 tonnes/hac). Variety Climax (2840tons/ha) and Sarsabz (2489 ton/ha) ranked third in yield respectively.

\section{Conclusion and Recommendation}

It is concluded from experiment that Meteor Pea varity gave the significant results from germination till harvesting. Under agro climatic condition of hazara division, variety Meteor gave maximum seed germination (92\%), days to $50 \%$ flowering (63.6\%), number of branches per plant (5.4), plant height (65.3), number of pods (14.5), pod length (8.3), pod weight (242) and seed weight (19.7). Maximum yield of Meteor (3585 tons/hac). The variety Meteor being the highest yielder can be recommended to the pea growers of Hazara division for commercial cultivation.

\section{Bibliography}

1. McPhee K. "Dry pea production and breeding - A minireview". Food, Agriculture and Environment 1 (2003): 64-69.

2. Urbano G., et al. "Nutritional evaluation of pea (Pisum sativum L.) protein diets after mild hydrothermal treatment and with and without added phytase". Journal of Agricultural and Food Chemistry 51 (2003): 2415-2420.

3. Habib N and M Zamin. "Offseason pea cultivation in Dir Kohistan valley". Asian Journal of Plant Science 2 (2003): 283285.

4. Agristastics of Pakistan, 2015-16. 
5. Santalla M., et al. "Food and feed potential breeding value of green, dry and vegetable pea germplasm”. Canadian Journal of Plant Science 81 (2001): 601-610.

6. Khan MH., et al. "Effect of different herbicides on controlling weeds and their effect on yield and yield components of edible pea (L.)". Pakistan Journal of Weed Science Research 9 (2003): 81-87.

7. Prakash V., et al. "Integrated weed management in garden pea under mid-hills of north-west Himalayas". Indian Journal of Weed Science 32 (2000): 7-11.

8. McPhee KE and FJ Muehlbauer. "Biomass production and related characters in the core collection of Pisum germplasm". Genetic Resources and Crop Evolution 48 (2001): 195-203.

9. Rutter L M and Randel R D. "Postpartum nutrient intake and body condition: effect on pituitary function and onset of estrus in beef cattle". Journal of Animal Science 58.2 (1984): 265-274.

10. Kumar A., et al. "Genetic parameters and character association in garden pea cultivars". Vegetation Science 35 (2008): 160164.

11. Vasil V., et al. "Herbicide resistant fertile transgenic wheat plants obtained by microprojectile bombardment of regenerable embryogenic callus". Bio/technology 10.6 (1992): 667-674.

12. Amjad M and Anjum M A. "Performance of nine pea cultivars under Faisalabad conditions". Pakistan Journal of Agricultural Sciences 39 (2002): 6-19.

13. Habtamu S and Million F. "Multivariate analysis of some Ethiopian field pea (Pisum sativum L.) genotypes". International Journal of Genetics and Molecular Biology 5.6 (2013): 78-87.

14. Maxted N and Ambrose M. "Peas (Pisum L.). In Plant genetic resources of legumes in the Mediterranean" (2001): 181-190.

15. Wu C., et al. "Simultaneous targeting of multiple disease mediators by a dual-variable-domain immunoglobulin". Nature Biotechnology 25.11 (2007): 1290-1297.

16. Hatam M Amanullah. "Grain yield potential of filed pea (Pisumsativum L) germplasm". Asian Journal of Plant Science 1.2 (2002): 180-181.

17. Hussain SA and Hussain M. "Performance and economic evaluation of pea varieties at two altitudes inkaghan valley". 21.4 (2006): 587-589.
Volume 5 Issue 10 October 2021 (C) All rights are reserved by Haq Nawaz, et al. 